\title{
Dietary conjugated linoleic acid has limited effects on tissue protein anabolism in sedentary and exercising adult rats
}

\author{
Philippe PATUREAU MIRAND ${ }^{\mathrm{a} *}$, Laurent MOSONI ${ }^{\mathrm{a}}$, \\ Marie-Agnès ARNAL-BAGNARD ${ }^{\mathrm{a}}$, Yannick FAULCONNIER ${ }^{\mathrm{b}}$, \\ Jean-Michel CHARDIGNY ${ }^{\mathrm{a}}$, Yves CHILLIARD ${ }^{\mathrm{b}}$ \\ a INRA, UMR 1019, Clermont-Ferrand - Theix, 63122 Theix, France; CRNH Auvergne, 63001 \\ Clermont-Ferrand, France \\ ${ }^{\mathrm{b}}$ Unité Recherches sur les Herbivores, Centre INRA de Clermont-Ferrand - Theix, 63122 Theix, France
}

(Received 14 March 2006; accepted 12 June 2006)

\begin{abstract}
The effects of conjugated linoleic acid isomers (CLA) and endurance training on lean body mass are expected to result from their action on tissue protein metabolism. The aim of this study was to analyze their effects on protein metabolism in 2 muscles, the small intestine and liver of adult rats. Four-month-old male Wistar rats were fed diets containing either no CLA, cis-9, trans-11 CLA isomer $\left(1 \mathrm{~g} .100 \mathrm{~g}^{-1}\right)$, trans-10, cis-12 CLA isomer $\left(1 \mathrm{~g} .100 \mathrm{~g} \mathrm{~g}^{-1}\right)$ or both isomers $\left(1 \mathrm{~g} .100 \mathrm{~g}^{-1}\right.$ each) for 6 weeks. Half of the rats were subjected to endurance training by running on a treadmill. At the end of this period, the rats were injected with a flooding dose of ${ }^{13} \mathrm{C}$-valine to determine protein synthesis rates in the post-absorptive (experiment 1 ) and in the post-prandial (experiment 2) states. No effect of CLA or endurance training were detected in the small intestine. Training reduced food intake and protein synthesis rates in the liver but no effect was found on the protein synthesis rates in muscles. In the post-absorptive state, protein synthesis rate was increased by feeding the trans-10, cis-12 CLA isomer alone in the liver $(+9 \%)$ or in combination with the cis-9, trans-11 isomer in the gastrocnemius $(+30 \%)$, mostly in sedentary rats. In the post-prandial state, the cis-9, trans-11 CLA isomer tended to reduce the protein synthesis rate in the gastrocnemius muscle. However, no effect of CLA was found on muscle protein amounts. In conclusion, CLA isomers would have limited but differential effects on tissue protein metabolism in adult rats.
\end{abstract}

conjugated linoleic acid / protein metabolism / exercise / muscle / liver / intestine

\section{INTRODUCTION}

Mixtures of conjugated linoleic acid isomers (CLA) were initially shown to reduce the percentage of whole body fat and/or the mass of fat pads, in mice [1] and then in rats, hamsters, pigs and hu-

\footnotetext{
* Corresponding author:

patureau@clermont.inra.fr
}

mans (see [2,3] for reviews). However, in the latter species, the effects were less marked than in mice. This fat-lowering effect appeared to be mainly related to lipid metabolism alterations induced by the trans-10, cis-12 isomer. The effects of CLA feeding on lean body mass and on its main constituents, muscle and protein masses are less consistent. In some studies, 
CLA feeding had no effect on these parameters in mice [4], rats [5-10], hamsters $[9,11]$ and humans [12]. In other studies, CLA increased body protein concentration or lean body percentage without modification of absolute amounts, in mice [13-15], rats [16] and humans $[17,18]$. It has also been shown to increase lean mass, protein levels and muscle mass in mice [19-21], rats [22], pigs [23] and humans [1, 24, 25]. The discrepancies in the results, even within a specific species, suggest that several factors such as genotype, age, diet, or physical activity may interfere with CLA effects. It has been suggested that CLA could be most effective in reducing fat mass and increasing lean mass when combined with enhanced physical activity in humans [2] and endurance training in mice [21]. Whether or not the differential effects of CLA isomers that were reported for lipid metabolism [26,27] occur in the control of lean body mass, cannot be determined, because CLA isomer mixtures were used in all the experiments quoted above except two $[1,11]$. In addition, the mechanisms responsible for the effects of CLA on lean body mass are unknown, mostly because their effects on the balance between protein synthesis and degradation, which controls tissue protein content and lean body mass, have not yet been described. Furthermore it can be assumed that their effects on protein metabolism can be detected more precociously on protein turnover than on protein contents.

The purpose of this study was therefore to determine whether feeding the two main isomers of CLA separately or together can modify protein metabolism in skeletal muscles or in splanchnic organs in adult rats in spite of limited effects on body composition [5] . A possible interaction with endurance training that was recently shown to enhance CLA effects on lean body mass in mice [21], was simultaneously tested. Since protein synthesis and degradation rates depend on nutritional state [28], their responses to CLA feeding and endurance training could be different in the post-absorptive and in the postprandial states. Consequently, the effects of CLA feeding and endurance training were studied in two separate experiments, the first in the post-absorptive state and the second in the post-prandial state.

\section{MATERIAL AND METHODS}

\subsection{Animals, diets and endurance training}

All procedures were performed according to current legislation on animal experimentation in France. In each experiment, 48 male Wistar rats aged 4 mo were purchased from Iffa-Credo/Charles River (L'Arbresle, France). They were maintained in individual wire-bottom cages at $21{ }^{\circ} \mathrm{C}$ with 12:12-h light-dark cycle (lights on at $2000 \mathrm{~h}$ ) and free access to tap water. The adaptation period lasted $7 \mathrm{~d}$. The 48 rats were then randomly divided into 2 groups. One group $(n=24)$, termed the trained rats, was exercised by treadmill running. The animals were progressively adapted during the first week to run for one hour at approximately $22 \mathrm{~m} / \mathrm{min}$ (i.e. no more than $50 \% \mathrm{VO}_{2} \max$ ). They were trained for $6 \mathrm{wk}, 6 \mathrm{~d} / \mathrm{wk}$ during the dark period (at $1500 \mathrm{~h})$. The other group $(n=24)$, the sedentary rats, had no exercise.

In each group, six animals were assigned to one of the four diets studied: the control diet, the control diet with $1 \%$ cis9, trans-11 CLA (diet c9,t11), the control diet with $1 \%$ trans-10, cis-12 CLA (diet $\mathrm{t} 10, \mathrm{c} 12)$ and the control diet with $1 \%$ cis9, trans- 11 and $1 \%$ trans- 10 , cis-12 CLA (diet Mix). The 4 diets had the same basal composition $\left(\mathrm{g} \cdot \mathrm{kg}^{-1}\right)$ : casein 180 , maize starch 430 , sucrose 210 , cellulose 20 , mineral mixture 50, vitamin mixture + DL methionine 10 and oil mixture 100 . They differed in the composition of the oil mixture (Tab. I). The CLA isomers provided as 
Table I. Composition of the oil mixtures.

\begin{tabular}{|c|c|c|c|c|}
\hline \multirow[t]{2}{*}{ Diets } & Control & $\mathrm{c} 9, \mathrm{t} 11$ & $\mathrm{t} 10, \mathrm{c} 12$ & Mix \\
\hline & \multicolumn{4}{|c|}{ (g per kg of diet) } \\
\hline Oleisol $^{1}$ & 98.4 & 88.4 & 88.4 & 78.4 \\
\hline Linseed oil & 1.6 & 1.6 & 1.6 & 1.6 \\
\hline Cis- 9, trans -11 CLA $^{2} \%$ & & 10 & & 10 \\
\hline Trans- 10, cis- 12 CLA $^{3} \%$ & & & 10 & 10 \\
\hline Total fat & 100 & 100 & 100 & 100 \\
\hline
\end{tabular}

${ }^{1}$ Sunflower oil rich in oleic acid.

2 The fatty acid composition of the cis-9, trans-11 source was the following (\%): oleic acid 1.5, cis-9, trans-11 CLA 96.1, trans-10, cis-12 CLA 1.4, other CLA 0.3 (Natural Lipids, Hovdebygda, Norway).

3 The fatty acid composition of the trans-10, cis-12 CLA source was the following (\%): palmitic acid 0.8, stearic acid 0.3, oleic acid 0.3, cis-9, trans-11 CLA 3.0,trans-10, cis-12 CLA 93.2, other CLA 1.4 (Natural Lipids, Hovdebygda, Norway).

triglycerides (Natural Lipids, Hovdebygda, Norway), were substituted for sunflower oil. The diets were fed at the beginning of the dark period $(0800 \mathrm{~h})$, in a semi-liquid form in order to have better control of food intake. The rats were fed these diets ad libitum for 6 wk. During this period, daily food intake was measured $5 \mathrm{~d} / \mathrm{wk}$ and the rats were weighed 3 times/wk. The mean initial body weights of the rats were nearly identical in all groups within each experiment (mean \pm SEM: $434 \pm 1$ and $465 \pm 1 \mathrm{~g}$ in experiments 1 and 2, respectively).

\subsection{Determination of tissue protein turnover}

Variations in lean body mass depend mainly on variations in protein amounts that result from the difference between protein synthesis and degradation rates. Protein synthetic activity in an organ can be assessed by its fractional synthesis rate (FSR, \%.d $\mathrm{d}^{-1}$ ) which is the percentage of tissue protein that is synthesized per day. An alteration in the overall efficiency of protein synthesis mechanisms can be detected by comparing translational efficiency [29]. Protein degradation rates were not determined directly but in muscles their variations could be detected because they result from the difference between protein synthesis and protein gain, which could be assessed. This reasoning cannot be applied to the liver and intestines because of protein export.

The synthesis rates of tissue proteins as a whole were determined at the end of the 6-wk experimental period. In experiment 1 , rats were in the post-absorptive state: food had been withdrawn at the end of the dark period, 13 to $16 \mathrm{~h}$ before measurements performed between $0900 \mathrm{~h}$ and $1200 \mathrm{~h}$. In experiment 2, the rats were in the post-prandial state: daily food was offered at the beginning of the dark period, 5 to $8 \mathrm{~h}$ before measurements and was still available at the time of killing, between $1300 \mathrm{~h}$ and $1600 \mathrm{~h}$. In trained rats, the determination of protein synthesis rates occurred at the same times as in sedentary rats. For each trained rat, it was $18 \mathrm{~h} 30 \mathrm{~min}-19 \mathrm{~h}$ after the end of the one-hour bout of exercise in experiment 1 and $23 \mathrm{~h} 15 \mathrm{~min}-23 \mathrm{~h} 45 \mathrm{~min}$ in experiment 2. Tissue protein synthesis rates were measured using the flooding dose method [30]. Briefly, each rat was injected with a flooding dose of $\mathrm{L}^{-13} \mathrm{C}$ valine (150 umoles. $100 \mathrm{~g}^{-1}$ body, 50 atom\%) in a lateral tail vein. General anesthesia 
was induced by intraperitoneal injection of pentobarbital sodium just before killing by exsanguination, which occurred $15 \mathrm{~min}$ after the ${ }^{13} \mathrm{C}$ valine injection. The liver, small intestine, gastrocnemius (plus plantaris) and soleus muscles were quickly excised and chilled on ice to stop tracer incorporation. The liver was cut into small pieces, rinsed in cold saline and wiped. The small intestine was rinsed with cold trichloroacetic acid $(0.12 \mathrm{M})$. All tissues were weighed and frozen in liquid nitrogen 3-5 min after exsanguination. This extra time was not allowed for in the calculation of incorporation time. In vivo fractional synthesis rates (FSR, \%.d $\mathrm{d}^{-1}$ ) of tissue proteins were calculated according to the following: FSR $=100 \times($ EP-EN $) /($ EA $\times$ t $)$ where $\mathrm{EP}$ and $\mathrm{EA}$ are the ${ }^{13} \mathrm{C}$ enrichments of protein-bound valine and of free valine respectively, at the end of the incorporation time. EN is an estimation of the natural ${ }^{13} \mathrm{C}$ enrichment of protein-bound valine (before flooding dose injection); it was determined in 4 additional rats fed the same diets as the experimental rats. The ${ }^{13} \mathrm{C}$ enrichments were determined by gas chromatographycombustion-isotope ratio mass spectrometry (GC-C-IRMS) for protein-bound valine and by GC-MS for tissue-free valine according to the methods described [31]. Tissue protein and RNA concentration were determined according to the bicinchoninic acid method [32] and the method of Manchester and Harris [33], respectively. Translational efficiency was calculated as the amount of protein synthesized (mg) per day per mg RNA.

\subsection{Statistical analyses}

Values in the text are given as means \pm SEM. The experimental schedule allows to determine the effects of diet, endurance training and their interaction on protein metabolism in each nutritional state but not those of nutritional state. They were ana- lyzed in each experiment separately using a two-way ANOVA (StatView statistical software package, version 5, SAS Institute, Cary, NC, USA). When diet effect was significant, the 4 diets were compared by contrast analysis. Differences were considered to be significant at $P<0.05$ in two-sided tests.

\section{RESULTS}

In both experiments, final body weight and food intake were not affected by CLA feeding but significantly $(P<0.01)$ reduced $(-11 \%)$ by endurance training (Tab. II).

\subsection{Protein metabolism during the post-absorptive state (experiment 1)}

In the gastrocnemius muscle, CLA feeding had no detectable effect on protein amount (Tab. III). However protein FSR in the rats fed the Mix diet was significantly higher $(P<0.01)$ than in the rats fed the diets lacking the trans-10, cis-12 isomer (diets Control and c9,t11) but no difference with that in the rats fed the t10,c12 diet was found. There was also significant interaction between CLA feeding and endurance training for FSR and translational efficiency: the effect of the Mix diet was significant in the sedentary rats only (Fig. 1A for FSR; not shown for translational efficiency).

In the soleus muscle, the only significant effect observed was this interaction between CLA feeding and endurance training for FSR and translational efficiency (Tab. III and Fig. 1B).

In the small intestine, no significant effect of CLA feeding on protein amount, FSR and translational efficiency was detected (Tab. IV). No effect of training on intestinal protein amount and FSR was 
Table II. Effects of CLA feeding and endurance training on body weights, food intakes and weight gains in the rats of experiment 1 (post-absorptive state) and experiment 2 (post-prandial state).

\begin{tabular}{|c|c|c|c|c|}
\hline \multirow[t]{3}{*}{ Diets } & \multicolumn{4}{|c|}{ Experiment 1} \\
\hline & \multicolumn{2}{|c|}{ Sedentary rats } & \multicolumn{2}{|c|}{ Trained rats } \\
\hline & $\begin{array}{l}\text { Final body weight } \\
\text { (g) }\end{array}$ & $\begin{array}{l}\text { Food intake } \\
\qquad\left(\mathrm{g} \cdot \mathrm{d}^{-1}\right)\end{array}$ & $\begin{array}{l}\text { Final body weight } \\
\qquad(\mathrm{g})\end{array}$ & $\begin{array}{l}\text { Food intake } \\
\qquad\left(\mathrm{g} \cdot \mathrm{d}^{-1}\right)\end{array}$ \\
\hline Control & $522 \pm 25$ & $20.16 \pm 0.83$ & $469 \pm 15$ & $18.71 \pm 0.35$ \\
\hline c9,t11 & $520 \pm 17$ & $20.96 \pm 0.53$ & $448 \pm 21$ & $18.34 \pm 0.68$ \\
\hline $\mathrm{t} 10, \mathrm{c} 12$ & $530 \pm 22$ & $20.78 \pm 0.81$ & $470 \pm 17$ & $18.26 \pm 0.75$ \\
\hline Mixed & $469 \pm 15$ & $20.70 \pm 0.37$ & $466 \pm 16$ & $19.05 \pm 0.72$ \\
\hline \multirow[t]{3}{*}{ Diets } & \multicolumn{4}{|c|}{ Experiment 2} \\
\hline & \multicolumn{2}{|c|}{ Sedentary rats } & \multicolumn{2}{|c|}{ Trained rats } \\
\hline & $\begin{array}{c}\text { Final body weight } \\
(\mathrm{g})\end{array}$ & $\begin{array}{l}\text { Food intake } \\
\qquad\left(\mathrm{g} \cdot \mathrm{d}^{-1}\right)\end{array}$ & $\begin{array}{l}\text { Final body weight } \\
(\mathrm{g})\end{array}$ & $\begin{array}{l}\text { Food intake } \\
\qquad\left(\mathrm{g} \cdot \mathrm{d}^{-1}\right)\end{array}$ \\
\hline Control & $558 \pm 6$ & $21.07 \pm 0.14$ & $498 \pm 11$ & $18.57 \pm 0.20$ \\
\hline c9,t11 & $562 \pm 22$ & $20.80 \pm 0.66$ & $503 \pm 11$ & $18.63 \pm 0.38$ \\
\hline $\mathrm{t} 10, \mathrm{c} 12$ & $541 \pm 21$ & $20.16 \pm 0.90$ & $502 \pm 12$ & $18.17 \pm 0.58$ \\
\hline Mixed & $536 \pm 6$ & $19.36 \pm 0.71$ & $481 \pm 18$ & $17.32 \pm 1.13$ \\
\hline
\end{tabular}

Means \pm SEM. Number of animals $=6$ in all groups except in experiment 2 , in the sedentary rats fed the control diet and in the trained rats fed the t10,c12 diet where it was 5. Anova indicated no significant effect of diet but a significant effect of training $(P<0.01)$ for final body weight and food intake, in the two experiments.

shown. However, translational efficiency was significantly $(P<0.001)$ higher $(+32 \%)$ in the trained rats than in the sedentary rats. Furthermore, there was a significant interaction $(P=0.04)$ between CLA feeding and endurance training since translational efficiency was significantly higher with the c9,t11 diet than with the Mix diet, in the trained rats only (Fig. 1C).

In the liver, feeding the $\mathrm{t} 10, \mathrm{c} 12$ diet significantly $(P=0.03)$ increased both FSR $(+10 \%)$ and translational efficiency $(+11 \%)$ when compared to the three other diets. Endurance training significantly $(P<0.01)$ decreased $(-9 \%)$ protein FSR but had no effect on its protein amount (Tab. IV). The significant interaction between CLA feeding and endurance training corresponded to the fact that feeding the Mix diet decreased FSR and translational efficiency only in the trained rats (FSR, $P=0.03$, Fig. 1D; translational efficiency, $P=0.05$, not shown).

\subsection{Protein metabolism during the post-prandial period (experiment 2)}

Both diet and endurance training effects on protein metabolism were less pronounced in the post-prandial state than in the post-absorptive state.

In the gastrocnemius muscle, no effect of diet or endurance training on muscle protein amount, or translational efficiency was detected (not shown). However, the diets tended to have a significant $(P=0.07)$ effect on protein FSR which was significantly lower with the $\mathrm{c} 9, \mathrm{t} 11$ diet than with the Control $(-17 \%)$ or t10,c12 $(-13 \%)$ diets in sedentary and trained rats. With the Mix diet, it was not significantly different from the other 3 diets (Fig. 2).

In the soleus muscle, no effect of diet or endurance training was observed on protein synthesis rates (data not shown). 
Table III. Effects of conjugated linoleic acid intake and endurance training on protein amount and fractional synthesis rates in the gastrocnemius and soleus muscle of post-absorptive rats (experiment 1).

\begin{tabular}{|c|c|c|c|c|c|c|c|c|}
\hline & \multicolumn{4}{|c|}{ Diet } & \multicolumn{2}{|c|}{ Endurance training } & \multirow{2}{*}{$\begin{array}{l}\text { Residual } \\
\text { standard } \\
\text { deviation }\end{array}$} & \multirow{2}{*}{$\begin{array}{l}\text { Significant } \\
\text { factors* }\end{array}$} \\
\hline & $\overline{\text { Control }}$ & $\mathrm{c9}, \mathrm{t} 11$ & $\mathrm{t} 10, \mathrm{c} 12$ & $\overline{\text { Mix }}$ & Sedentary & Trained & & \\
\hline Number of rats & 12 & 11 & 12 & 11 & 23 & 23 & & \\
\hline \multicolumn{9}{|l|}{ Gastrocnemius } \\
\hline Protein amount, $\mathrm{g}$ & 0.556 & 0.572 & 0.553 & 0.550 & 0.579 & 0.536 & 0.064 & $\mathrm{~T}$ \\
\hline $\begin{array}{l}\text { Fractional synthesis rate, } \\
\% . \mathrm{d}^{-1}\end{array}$ & $5.84^{\mathrm{a}}$ & $6.24^{\mathrm{a}}$ & $6.79^{\mathrm{ab}}$ & $7.59^{\mathrm{b}}$ & 7.01 & 6.19 & 1.42 & $\mathrm{D}, \mathrm{D} \times \mathrm{T}$ \\
\hline $\begin{array}{l}\text { Translational efficiency, } \\
\text { mg prot/(d.mg RNA) }\end{array}$ & 12.3 & 14.0 & 14.4 & 15.6 & 14.4 & 13.7 & 4.0 & $\mathrm{D} \times \mathrm{T}$ \\
\hline \multicolumn{9}{|l|}{ Soleus } \\
\hline Protein amount, mg & 34.6 & 32.8 & 34.8 & 32.4 & 34.5 & 32.8 & 3.9 & \\
\hline $\begin{array}{l}\text { Fractional synthesis rate, } \\
\% . \mathrm{d}^{-1}\end{array}$ & 9.99 & 10.00 & 10.30 & 10.80 & 10.00 & 10.53 & 1.77 & $\mathrm{D} \times \mathrm{T}$ \\
\hline $\begin{array}{l}\text { Translational efficiency, } \\
\text { mg prot/(d.mg RNA) }\end{array}$ & 12.2 & 12.0 & 12.8 & 13.3 & 12.6 & 12.5 & 4.0 & $\mathrm{D} \times \mathrm{T}$ \\
\hline
\end{tabular}

Means of the main effects, diet or endurance training.

* Significant factors $(P \leq 0.05)$ : $\mathrm{D}$ : diet, $\mathrm{T}$ : endurance training, $\mathrm{D} \times \mathrm{T}$ : interaction diet $\times$ endurance training. a,b within diet factor, the values with a common superscript cannot be considered as different $(P<0.05)$.

In the small intestine, neither diet nor endurance training effects on protein amount or protein synthesis rates could be detected (data not shown).

In the liver, none of these parameters were affected by diet but they were significantly lower $(P<0.01)$ in the trained rats than in the sedentary rats being respectively (means \pm SEM, $n=23$ ) $2.90 \pm$ 0.06 and $3.35 \pm 0.07 \mathrm{~g}$ for the protein amount, $55.5 \pm 1.9$ and $63.3 \pm 1.4 \% \cdot \mathrm{d}^{-1}$ for the fractional synthesis rate, $15.0 \pm 0.5$ and $17.4 \pm 0.4 \mathrm{mg}$ protein/(d.mg RNA) for translational efficiency.

\section{DISCUSSION}

\subsection{Effect of CLA feeding}

In this study, few effects of CLA isomer feeding on protein metabolism were observed. The most pronounced effects were a stimulation of protein synthesis by the Mix diet in muscle and by the $t 10, c 12$ diet in the liver during the post-absorptive period. This stimulatory effect was mainly observed in muscles of the sedentary rats. This difference in gastrocnemius FSR protein, between the sedentary rats fed the Mix diet $\left(8.5 \pm 0.6 \% . \mathrm{d}^{-1}\right)$ and the $\mathrm{c} 9, \mathrm{t} 11$ $\operatorname{diet}\left(5.5 \pm 0.4 \% . \mathrm{d}^{-1}\right)$ was similar to the difference observed previously for 7-wk-old rats fed ad libitum or a $50 \%$ energy restricted diet for 4 weeks: 8.6 vs. $5.7 \% . \mathrm{d}^{-1}$ [34]. Such a difference in non specific protein synthesis rates was expected to have an impact on muscle protein amounts except if a stimulation of protein degradation was associated. The lack of diet effect on muscle protein amount suggests that both protein synthesis and degradation were stimulated by the Mix diet. The effect of this diet on muscle protein turnover could be a specific effect of the isomer 
Gastrocnemius (A)

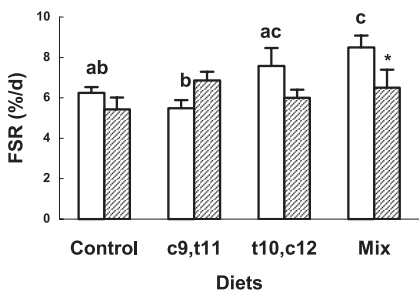

Small intestine (C)

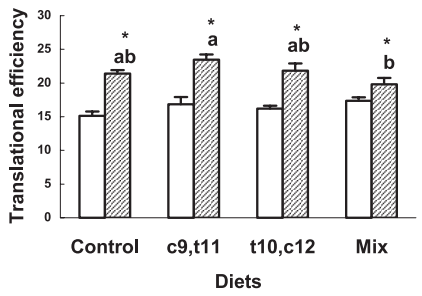

Soleus (B)

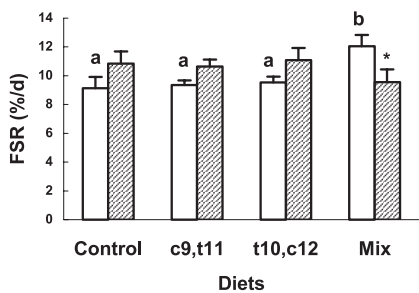

Liver (D)

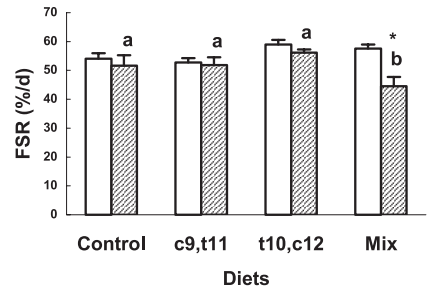

Figure 1. Effect of CLA feeding and endurance training on fractional protein synthesis $\left(\% \cdot \mathrm{d}^{-1}\right)$ rates in muscles and liver and on translational efficiency (mg protein/(mg RNA $\times \mathrm{d}))$ in the small intestine of post-absorptive rats (experiment 1). Means $\pm \mathrm{SEM}, \mathrm{n}=6$. Diet Control: control diet; diet c9,t11: control diet with $1 \%$ cis-9, trans-11 CLA isomer; diet t10,c12: control diet with $1 \%$ trans-10, cis-12 CLA isomer, diet Mix, control diet with $1 \%$ of both isomers. $\square$ Sedentary rats $\square \Delta$ Trained rats; $n=6$ for most groups except sedentary rats fed the Control diet and trained rats fed the t10,c12 diet where $n=5$. * Significantly different from sedentary rats $(P<0.05)$. abc Within either sedentary rats or trained rats, the bars sharing the same superscripts cannot be considered as different at $P<0.05$.

mixture or an enhancement of the effect of the trans-10, cis-12 isomer by the cis-9, trans-11 isomer as suggested by the results in gastrocnemius. In the latter, FSR were indeed the highest with the 2 diets containing the trans-10, cis-12 isomer, in particular when both isomers were fed simultaneously (Mix diet).

The increase in muscle and liver protein turnover in the post-absorptive state would result in a slight increase in energy expenditure. Slight $(+3-4 \%)[14,19]$ and more elevated increases $(+7-16 \%)[35,36]$ in energy expenditure have been reported in mice fed a CLA mixture, and in obese rats $(+12 \%$ with the trans -10 , cis-12 CLA) [37], where they resulted in a decrease in fat mass. However it was only in the trained group that feeding a CLA mixture increased energy expenditure in Balb/C mice [21].

It is likely that the stimulation of muscle and liver protein turnover during the postabsorptive period by feeding the trans -10 , cis-12 CLA in the present experiments, did not result in a marked increase in energy expenditure because no effect was observed on body composition in adult rats fed ad libitum [5, 27]. However, these rats probably never experienced a postabsorptive period as long as that created when protein synthesis rates were determined i.e. $13-16 \mathrm{~h}$. This suggests that the still debated fat-lowering effect of trans10, cis-12 CLA could be enhanced by long post-absorptive periods, in agreement with 
Table IV. Effects of conjugated linoleic acid intake and endurance training on protein amount and fractional synthesis rates in the small intestine and liver of post-absorptive rats (experiment 1).

\begin{tabular}{|c|c|c|c|c|c|c|c|c|}
\hline & \multicolumn{4}{|c|}{ Diet } & \multicolumn{2}{|c|}{ Endurance training } & \multirow{2}{*}{$\begin{array}{l}\text { Residual } \\
\text { standard } \\
\text { deviation }\end{array}$} & \multirow{2}{*}{$\begin{array}{c}\text { Significant } \\
\text { factors* }\end{array}$} \\
\hline & $\overline{\text { Control }}$ & $\mathrm{c} 9, \mathrm{t} 11$ & $\mathrm{t} 10, \mathrm{c} 12$ & Mix & Sedentary & Trained & & \\
\hline Number of rats & 12 & 12 & 12 & 12 & 23 & 23 & & \\
\hline \multicolumn{9}{|l|}{ Small intestine } \\
\hline Protein amount, $\mathrm{g}$ & 0.882 & 0.865 & 0.908 & 0.923 & 0.905 & 0.884 & 0.134 & \\
\hline $\begin{array}{l}\text { Fractional synthesis rate, } \\
\% . \mathrm{d}^{-1}\end{array}$ & 74.0 & 77.4 & 76.5 & 77.2 & 75.3 & 77.3 & 6.1 & \\
\hline $\begin{array}{l}\text { Translational efficiency, } \\
\text { mg prot/(d.mg RNA) }\end{array}$ & 18.3 & 20.2 & 19.0 & 18.6 & 16.4 & 21.6 & 1.9 & $\mathrm{~T}, \mathrm{D} \times \mathrm{T}$ \\
\hline \multicolumn{9}{|l|}{ Liver } \\
\hline Protein amount $g$ & 2.64 & 2.57 & 2.70 & 2.84 & 2.66 & 2.72 & 0.33 & \\
\hline $\begin{array}{l}\text { Fractional synthesis rate } \\
\% . \mathrm{d}^{-1}\end{array}$ & $52.9^{\mathrm{a}}$ & $52.3^{\mathrm{a}}$ & $57.5^{\mathrm{b}}$ & $51.1^{\mathrm{a}}$ & 55.8 & 51.0 & 5.4 & $\mathrm{D}, \mathrm{T}, \mathrm{D} \times \mathrm{T}$ \\
\hline $\begin{array}{l}\text { Translational efficiency } \\
\text { mg prot/(d.mg RNA) }\end{array}$ & $12.9^{\mathrm{a}}$ & $13.2^{\mathrm{ab}}$ & $14.3^{\mathrm{b}}$ & $12.5^{\mathrm{a}}$ & 13.0 & 13.5 & 1.46 & $\mathrm{D}, \mathrm{D} \times \mathrm{T}$ \\
\hline
\end{tabular}

Means of the main effects, diet or endurance training

Significant factors $(P \leq 0.05)$ : D: diet, T: endurance training, $\mathrm{D} \times \mathrm{T}$ : interaction diet $\times$ endurance training. a,b within diet factor, the values with a common superscript cannot be considered as different $(P<0.05)$.

the results obtained in restricted rats [7] which usually experience such a feeding pattern.

Unlike that observed with trans-10, cis12 CLA in the post-absorptive state, the cis-9, trans-11 isomer tended to reduce post-prandial protein synthesis rates in gastrocnemius, mostly in the trained group where the difference reached 25\% (6.94 \pm 0.30 vs. $\left.5.25 \pm 0.42 \% \cdot \mathrm{d}^{-1}, P=0.01\right)$. Since this lowering effect on protein synthesis had no significant consequence on muscle protein amount, it is likely that it had the same lowering effect on protein degradation. Consequently, each isomer appears to have different effects on muscle protein metabolism in adult rats: the trans-10, cis-12 CLA stimulating protein turnover in non anabolic (post-absorptive) conditions and the cis-9, trans- 11 isomer lowering it in anabolic (post-prandial) conditions. Similarly, these two isomers were shown to have different effects on lipid metabolism and the effects differed between rats and mice [26, 27]. Such effects were consistent with limited effects on body composition in adult rats fed ad libitum [5]. Indeed protein synthesis and degradation appear to vary in a similar way and consequently this may have only minor effects on protein amounts. Furthermore, the potential increase in energy expenditure could be small if occurring mainly during the post-absorptive period which is likely to be short in ad libitum fed rats. Whether similar results would be obtained in younger rats and/or with higher CLA doses than those used in the present experiments remains a debatable point.

\subsection{Effect of endurance training}

Calculated from the data of both experiments, gastrocnemius and soleus protein amounts were lower in the trained rats $(534 \pm 9$ and $32.7 \pm 0.5 \mathrm{mg}$ respectively) 


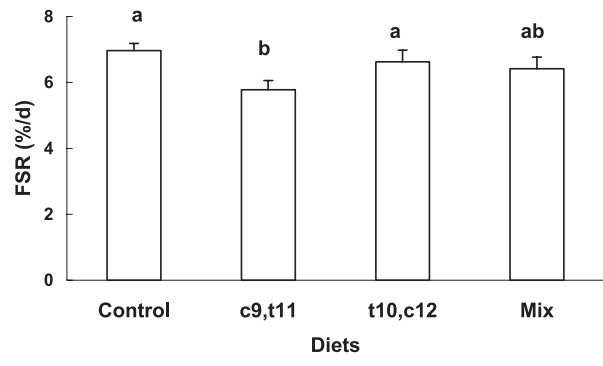

Figure 2. Effect of CLA isomer feeding on fractional protein synthesis rates in gastrocnemius muscle of post-prandial rats (experiment 2). Means of the pooled data from sedentary and trained rats \pm SEM because there was no significant effect of endurance training. Control diet: control diet; $\mathrm{c9}, \mathrm{t11}$ diet: control diet with 1\% cis-9, trans-11 CLA isomer; t10,c12 diet: control diet with $1 \%$ trans-10, cis-12 CLA isomer; Mix diet, control diet with $1 \%$ of both isomers. $n=12$ for most groups except in rats fed the control diet and the $110, \mathrm{c} 12$ diet where $n=11$. There was a tendency for a diet effect $(P=0.07)$ and no significant effects of endurance training or of the interaction in the two-factor anova. ab The bars sharing the same superscripts cannot be considered as different at $P<0.05$.

than in the sedentary rats $(558 \pm 9$ and $35.4 \pm 0.6 \mathrm{mg}$ ). In contrast, the relative protein amounts of these muscles (mg of protein per $100 \mathrm{~g}$ empty body weight) were higher in the trained rats for gastrocnemius $(114 \pm 2$ vs. $106 \pm 2 \mathrm{mg}, P<0.01)$ but not for soleus $(6.98 \pm 0.12 \mathrm{vs} .6 .75 \pm 0.11 \mathrm{mg})$. This indicates that the growth inhibition resulting from endurance training (and the associated decreased voluntary food intake) was lower for the gastrocnemius than for the whole body. A similar effect of training was described for the quadriceps muscle [38] and the tibialis anterior muscle [39] in rats that experienced a similar exercise-induced decrease in food intake. The absence of an endurance training effect on muscle protein synthesis rates at rest, observed in the present study was in agree- ment with other results obtained in the tibialis anterior [39] and in the epitrochlearis [40] in rats. This conflicts with recent results in humans fed weight-maintaining diets reporting a stimulation at rest of muscle protein synthesis by endurance training $[41,42]$. The reason why protein fractional synthesis rates in the liver were lower at rest in trained rats than in sedentary rats remains unclear. It was proposed that a decrease in protein synthesis in the liver [43] or in the gut would reduce amino acid utilization in these organs and increase amino acid availability in peripheral organs like muscles [44] or for energy production.

In conclusion, the effect of endurance training with the corresponding slight food restriction appears to be limited. Furthermore, endurance training interacted slightly with the effect of CLA on tissue protein metabolism. Actually in this study, the trans-10, cis-12 CLA isomer (in a mixture or alone) stimulated muscle and liver protein turnover, and this effect was more marked in sedentary rats. It is likely, however, that this did not result in any fat-lowering effect by increasing energy expenditure in adult rats. This change in protein metabolism occurred indeed mostly in situations where protein turnover was low, such as in the postabsorptive sedentary rats. On the contrary, the cis-9, trans-11 isomer tended to reduce muscle protein turnover, in particular when protein turnover was stimulated such as in the post-prandial trained animals. Further experiments, taking into account the specific effects of each isomer are necessary to verify these conclusions and more specifically to investigate whether or not they depend on anabolic conditions like those observed with resistance training.

\section{ACKNOWLEDGEMENTS}

Christine Cubizolles and Christian Lafarge are thanked for management of the animal facilities and care for the rats, Marion Jamin 
and Jacques Prugnaud for biochemical analyses, and Hélène Lafarge and Danielle Bonin for their assistance with the literature survey. This study was carried out with financial support from the Commission of the European Communities, specific RTD program "Quality of Life and Management of Living Resources" QLK1CT99-00076 "Conjugated Linoleic Acid (CLA) in functional food: a potential benefit for overweight middle-aged Europeans (FunCLA)". It does not necessarily reflect the views of the Commision and in no way anticipates its future policy in this area.

\section{REFERENCES}

[1] Park Y, Albright KJ, Storkson JM, Liu W, Cook ME, Pariza MW. Changes in body composition in mice during feeding and withdrawal of conjugated linoleic acid. Lipids 1999, 34: 243-248.

[2] Pariza MW. Perspective on the safety and effectiveness of conjugated linoleic acid. Am J Clin Nutr 2004, 79: 1132S-1136S.

[3] Terpstra AHM. Effect of conjugated linoleic acid on body composition and plasma lipids in humans: an overview of the literature. Am J Clin Nutr 2004, 79: 352-361.

[4] Tsuboyama-Kasaoka N, Takahashi M, Tanemura K, Kim HJ, Tange T, Okuyama H, Kasai M, Ikemoto S, Ezaki O. Conjugated linoleic acid supplementation reduces adipose tissue by apoptosis and develops lipodystrophy in mice. Diabetes 2000, 19: 1534-1542.

[5] Patureau Mirand P, Arnal-Bagnard MA, Mosoni L, Faulconnier Y, Chardigny JM, Chilliard Y. Cis-9, trans-11 and trans-10, cis-12 conjugated linoleic acid isomers do not modify body composition in adult sedentary or exercised rats. J Nutr 2004, 134: 2263-2269.

[6] Azain MJ, Hausman DB, Sisk MB, Flatt WP, Jewell DE. Dietary conjugated linoleic acid reduces rat adipose tissue cell size rather than cell number. J Nutr 2000, 130: 1548-1554.

[7] Stangl GI. Conjugated linoleic acids exhibit a strong fat-to lean partitioning effect, reduce serum VLDL lipids and redistribute tissue lipids in food-restricted rats. J Nutr 2000, 130: 1140-1146.
[8] Sisk MB, Hausman DB, Martin RJ, Azain MJ. Dietary conjugated linoleic acid reduces adiposity in lean but not obese Zucker rats. J Nutr 2001, 131: 1668-1674.

[9] Kim MR, Park Y, Albright KJ, Pariza MW. Differential responses of hamsters and rats fed high-fat or low-fat diets supplemented with conjugated linoleic acid. Nutr Res (NY) 2002, 22: 715-722.

[10] Mir PS, Okine EK, Goonewardene L, He ML, Mir Z. Effects of synthetic conjugated linoleic acid (CLA) or bio-formed cla as high cla beef on rat growth and adipose tissue development. Can J Anim Sci 2003, 83: 583 592.

[11] Bouthegourd JC, Even PC, Gripois D, Tiffon B, Blouquit MF, Roseau S, Lutton C, Tomé D, Martin JC. A CLA mixture prevents body triglyceride accumulation without affecting energy expenditure in Syrian hamsters. J Nutr 2002, 132, 2682-2689.

[12] Zambell KL, Keim NL, Van Loan MD, Gale B, Benito P, Kelley DS, Nelson GJ. Conjugated linoleic acid supplementation in humans: effects on body composition and energy expenditure. Lipids 2000, 35: 777-782.

[13] DeLany JP, Blohm F, Truett AA, Scimeca J, West DB. Conjugated linoleic acid reduces body fat content in mice without affecting energy intake. Am J Physiol 1999, 276: R1172-R1179.

[14] Terpstra AHM, Javadi M, Beynen AC, Kocsis S, Lankhorst AE, Lemmens AG, Mohede ICM. Dietary conjugated linoleic acids as free fatty acids and triacylglycerols similarly affect body composition and energy balance in mice. J Nutr 2003, 133: 31813186.

[15] Stangl GI. High dietary levels of a conjugated linoleic acid mixture alter hepatic glycerophospholipid class profile and cholesterol-carrying serum lipoproteins of rats. J Nutr Biochem 2000, 11: 184-191.

[16] Blankson H, Stakkestad JA, Fagertun H, Thom E, Wadstein J, Gudmundsen O. Conjugated linoleic acid reduces body fat mass in overweight and obese humans. J Nutr 2000, 130: 2943-2948.

[17] Berven G, Bye A, Hals O, Blankson $\mathrm{H}$, Fagertun $\mathrm{H}$, Thom E, Wadstein J, Gudmundsen O. Safety of conjugated linoleic acid (CLA) in overweight or obese human volunteers. Eur J Lipid Sci Technol 2000, 102: 455-462. 
[18] Ntambi JM, Choi Y, Park Y, Peters JM, Pariza MW. Effects of conjugated linoleic acid (CLA) on immune responses, body composition and stearoyl-CoA desaturase. Can J Appl Physiol 2002, 27: 617-627.

[19] Terpstra AHM, Beynen AC, Everts H, Kocsis $\mathrm{S}$, Katan MB, Zock PL. The decrease in body fat in mice fed conjugated linoleic acid is due to increases in energy expenditure and energy loss in the excreta. J Nutr 2002, 132: 940-945.

[20] Poulos SO, Sisk M, Hausman DB, Azain MJ, Hausman GJ. Pre- and postnatal dietary conjugated linoleic acid alters adipose development, body weight gain and body composition in Sprague-Dawley rats. J Nutr 2001, 131: 2722-2731.

[21] Bhattacharya A, Rahman MM, Sun D, Lawrence R, Mejia W, McCarter R, O'Shea $\mathrm{M}$, Fernandes G. The combination of dietary conjugated linoleic acid and treadmill exercise lowers gain in body fat mass and enhances lean body mass in high fat-fed male Balb/C mice. J Nutr 2005, 135, 1124-1130.

[22] Ostrowska E, Muralitharan M, Cross RF, Bauman DE, Dunshea FR. Dietary conjugated linoleic acids increase lean tissue and decrease fat deposition in growing pigs. J Nutr 1999, 129: 2037-2042.

[23] Kamphuis MMJW, Lejeune MPGM, Saris WHM, Westerterp-Plantenga MS. The effect of conjugated linoleic acid supplementation after weight loss on body weight regain, body composition, and resting metabolism rate in overweight subjects. Int J Obes 2003 , 27: 840-847.

[24] Gaullier JM, Berven G, Blankson H, Gudmundsen O. Clinical trial results support a preference for using CLA preparations enriched with two isomers rather than four isomers in human studies. Lipids 2002, 37: 1019-1025.

[25] Gaullier JM, Halse J, Hoye K, Kristiansen $\mathrm{K}$, Fagertun $\mathrm{H}$, Vik $\mathrm{H}$, Gudmundsen $\mathrm{O}$. Conjugated linoleic acid supplementation for $1 \mathrm{y}$ reduces body fat mass in healthy overweight humans. Am J Clin Nutr 2004, 79: 1118-1125.

[26] Roche HM, Noone E, Sweter C, Mc Bennett S, Savage D, Gibney MJ, O'Rahilly S, VidalPuig AJ. Isomer-dependent metabolic effects of conjugated linoleic acid - Insights from molecular markers sterol regulatory elementbinding protein-1c and $\operatorname{LXR} \alpha$. Diabetes 2002, 51: 2037-2044.
[27] Faulconnier Y, Arnal MA, Patureau Mirand $\mathrm{P}$, Chardigny JM, Chilliard Y. Isomers of conjugated linoleic acid decrease plasma lipids and stimulate adipose tissue lipogenesis without changing adipose tissue weight in post-prandial adult sedentary or trained Wistar rat. J Nutr Biochem 2004, 15: 741748.

[28] Pacy PJ, Price GM, Halliday D, Quevedo MR, Millward DJ. Nitrogen homoeostasis in man - the diurnal responses of protein synthesis and degradation and amino acid oxidation to diets with increasing protein intakes. Clin Sci 1994, 86: 103-118.

[29] Burrin DG, Davis T, Fiorotto ML, Reeds PJ. Stage of development and fasting affect protein synthetic activity in the gastrointestinal tissues of suckling rats. J Nutr 1991, 121: 1099-1108.

[30] Garlick PJ, McNurlan MA, Preedy VR. A rapid and convenient technique for measuring the rate of protein synthesis in tissues by injection of $[3 \mathrm{H}]$ phenylalanine. Biochem $\mathrm{J}$ 1980, 192: 719-723.

[31] Mercier S, Breuillé D, Mosoni L, Obled C, Patureau Mirand P. Chronic inflammation alters protein metabolism in several organs of adult rats. J Nutr 2002, 132: 1921-1928.

[32] Smith PK, Krohn RI, Hermanson GT, Mallia AK, Gartner FH, Provenzano MD, Fujimoto EK, Goeke NM, Olson BJ, Klenk DC. Measurement of protein using bicinchoninic acid. Anal Biochem 1985, 150: 76-85.

[33] Manchester KL, Harris EJ. Effect of denervation on the synthesis of ribonucleic acid and deoxyribonucleic acid in rat diaphragm muscle. Biochem J 1968, 108: 177-183.

[34] El Haj EJ, Lewis SEM, Goldspink DF, Merry BJ, Holehan AM. The effect of chronic and acute dietary restriction on the growth and protein turnover of fast and slow types of skeletal muscle. Comp Biochem Physiol 1986, 85A: 281-287.

[35] West DD, DeLany JP, Camet PM, Blohm F, Truett AA, Scimeca J. Effects of conjugated linoleic acid on body fat and energy metabolism in the mouse. Am J Physiol 1998, 275: R667-R672.

[36] West DB, Flohm FY, Truett AA, DeLany JP. Conjugated linoleic acid persistently increases total energy expenditure in AKR/J mice without increasing uncoupling protein gene expression. J Nutr 2000, 130: 24712477. 
[37] Nagao K, Wang YM, Inoue N, Han SY, Buang Y, Noda T, Kouda N, Okamatsu H, Yanagita T. The 10trans, 12cis isomer of conjugated linoleic acid promotes energy metabolism in OLEFT rats. Nutrition 2003, 19: 652-656.

[38] Askew EW, Dohm GL, Doub WH, Huston RL, Van Natta PA. Lipogenesis and glycerid synthesis in the rat: response to diet and exercise. J Nutr 1975, 105: 190-199.

[39] Mosoni L, Valluy MC, Serrurier B, Prugnaud J, Obled C, Guezennec CY, Patureau Mirand P. Altered response of protein synthesis to nutritional state and endurance training in old rats. Am J Physiol 1995, 268: E328E335.

[40] Davis TA, Karl IE, Tegtmeyer ED, Osborne DF, Klahr S, Harter HR. Muscle protein turnover: effects of exercise training and renal insufficiency. Am J Physiol 1985, 248: E337-E345.

[41] Short KR, Vittone JL, Bigelow ML, Proctor DN, Nair KS. Age and aerobic exercise training effects on whole body and muscle protein metabolism. Am J Physiol 2004, 286: E92E101.

[42] Pikoski MA, Gaine PC, Martin WF, Grabarz KC, Ferrando AA, Wolfe RR, Rodriguez NR. Aerobic exercise training increases skeletal muscle protein turnover in healthy adults at rest. J Nutr 2006, 136, 379-383.

[43] Dohm GL, Kasperek GJ, Tapscott EB, Barakat HA. Protein metabolism during endurance exercise. Fed Proc 1985, 44: 348352.

[44] Williams BD, Wolfe RR, Bracy DP, Wasserman DH. Gut proteolysis contributes essential amino acids during exercise. Am J Physiol 1996, 270: E85-E90. 